\title{
CONSTRUCTED WETLANDS AS A TREATMENT METHOD FOR LANDFILL LEACHATE
}

\author{
Lars Thörneby \\ Lund University \\ William Hogland \\ University College of Kalmar, Lund University \\ Kenneth Persson \\ $V B B$ VIAK $A B$ \\ Erling Alm \\ $A B A S S Y$ \\ Sweden
}

\section{ABSTRACT}

On-site treatment of landfill leachate may soon be recommended by the Swedish Environmental Protection Agency. Various methods and concepts are currently used or have been proposed to this end. This paper describes a treatment system for landfill leachate using a constructed wetland as a tool for; water volume reduction, leachate recycling, bioremoval of organics and nutrients, precipitation and adsorption of metals, gas production enhancement, gaseous emissions minimisation and as pre-treatment before a polishing step using other methods, for example, reverse osmosis. Assuming precipitation values corresponding to Southern Sweden a wetland covering $25 \%$ of the drained area will reduce the annual leachate flow by $30 \%$. If $80 \%$ is covered by wetland all precipitation will be lost as evapotranspiration. A test plant has been established at the Swedish waste company ASSY:s landfill in Hedeskoga, both a constructed wetland and the reverse osmosis pilot plant, to test the effectiveness of these methods. 


\section{ON-SITE TREATMENT OF LEACHATE}

Leachate may be treated on-site using the same methods as those used for the treatment of municipal sewage, i.e. sedimentation, biological treatment and screening. However, as the character of leachate differs from that of municipal sewage, these methods are not always successful.

From environmental point of view, the main concerns are organic compounds, nitrogen and heavy metals. The organic contents consist of easily decomposable substances measured as BOD and biochemically more persistent substances measured as the difference between COD and BOD. Generally, the nitrogen content in old leachate is in the form of ammonia-nitrogen. The metal content of leachate depends, of course, on the metal content in the waste content along with the $\mathrm{pH}$ and redox-potential of the leachate. These latter conditions in tum depends on whether or not the metal containing waste is co- disposed with organic matter.

There are three strategies to handle pollutants in leachate; transformation, concentration or dilution. The transformation of compounds to less environmentally hazardous substances may be done with biochemical, chemical or thermal methods. It is usually restricted to the leachate's organic and nitrogen content. The inorganic content must be treated using one of the other strategies.

Different treatment systems have been constructed to separate different groups of pollutants. A complete leachate treatment system consists, therefore, of a combination of several methods. For instance, biological systems can be combined with methods that remove compounds not available for biological treatment. The age or the decomposition phase of the landfill is of importance in selecting the appropriate treatment method.

\section{REVERSE OSMOSIS}

Membrane separation for industrial use was introduced in the early 1960s with the main objective of desalinating water with reverse osmosis (RO) and electrodialysis (ED). Today, membrane separation is an effective and economic tool in many applications (Rautenbach et al., 1989). The most important and significant characteristic of reverse osmosis compared with other membrane processes is its capability to retain monovalent ions.

A reverse osmosis pilot plant can consist of a module, a pressure vessel with a membrane, a high-pressure pump and a valve to maintain the pressure. In order to avoid damaging the pump, valve and membrane, the incoming water that is fed to the plant should be free from suspended material. Pre-treatment leads to longer operation time, longer life-time of the membrane and higher capacity between cleaning cycles (Marinas, 1991) Sometimes pre-treatment with chemicals is necessary to control scaling problems and feed pH (Jaeffer, 1994)

Reverse osmosis can be regarded as a sub-stage in the total immobilisation of hazardous substances (Rautenbach et al., 1996). If the retentate is infiltrated into 
the landfill (Henigin, 1995), RO can be compared with soil-vegetation systems where the evaporation is higher than the leachate production and no contaminated water is allowed to leak into the surroundings.

\section{WETLANDS}

A promising method for treating leachate is constructed wetlands; these can be used either for primary treatment - where the wetland is the only method of treatment - or secondary treatment after first settling out solids or, if necessary, removing BOD using other methods (Bavor, 1995). Treatment includes sedimentation, filtration, precipitation, adsorption, and transformation by bacterial and plant metabolism, chemical transformation and natural die-off.

Treatment of industrial or municipal sewage by subsurface wetlands was developed in Germany in the 1970s and has since then been used with varied results (Brix, 1987) (Kickuth, 1977). Many studies show a high level of organic matter reduction, but less removal of nitrogen (Robinson, 1993; Lind, 1996; MacIntyre and Riha, 1991a Davido et al., 1989; Gersberg et al., 1984). Generally, the leachate phosphorus content is low, therefore, the low reduction of nitrogen is the main limitation to the use of wetlands as the sole treatment method. Sometimes periodic draining and filling is used to provide oxygenated aerobic conditions alternating with reducing anaerobic conditions, as required to improve efficiency of nitrogen removal.

Metal removal is highly dependent on the kind of substrate used. Metals can be captured in sediment, adsorbed into inorganic and organic matter or can be precipitated out as insoluble sulphides in anaerobic parts of the wetland (Gersberg et al., 1983).

In the case of landfill leachate it is preferable to remove ferrous iron and manganese before wetland treatment. This is due to their ability to precipitate out, particularly in the aerobic zones, which causes adverse impacts on plants and the hydraulic conductivity of the bed.

Hydrological factors which determine the flow through a wetland are the standard water balance parameters; hydraulic conductivity of the substrate, annual variation in climate and depth of water. The wetland water balance can resolve the volumes of water lost to evapotranspiration and percolation to the ground water table. Normally, constructed wetlands are built with specially designed liners. Therefore evapotranspiration is the main the difference between inflow and outflow

Treatment efficiency generally increases with detention time (Wetsel, 1984). Precipitation increases the flow resulting in decreased contact time for different processes - at the same time, the pollutants are diluted which partly counteracts this. On the other hand, evaporative losses means increased detention times. Different flow patterns may be used in order to achieve a suitable detention time (Figure 1.) 


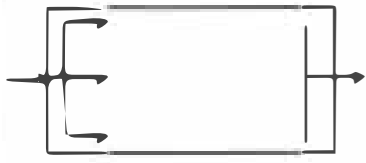

Plug flow

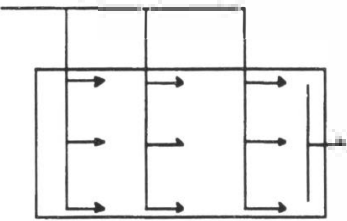

Step feed

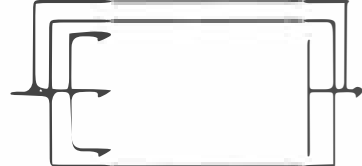

Recirculation

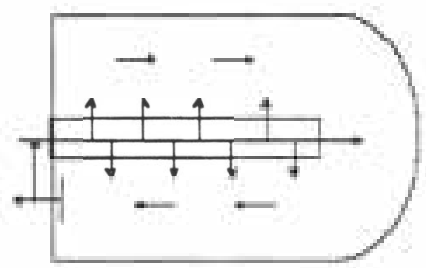

"Jelly roll" step feed-recirculation c ell

Fig. 1: Basic flow patterns for constructed wetlands. (After Steiner and Freeman)

The substrate determines the hydraulic load allowed without channels forming or overland flow both of which cause decreased treatment efficiency. The substrate is also a mechanical support for plants and microbes and participates in the treatment system as an adsorbent . The substrate material can be gravel, soil, peat or a mixture of these depending on the polluting substances concerned.

The potential evaporation, on annual basis at a landfill, is generally much higher than the actual evaporation due to periodic dryness of the top soil, particularly if the plants are not irrigated. The evaporation of an uncovered part of a landfill in Southem Sweden was less than $50 \%$ of the potential evaporation. At a covered part of the landfill, the evaporation was higher, about $60 \%$ of the potential evaporation. (Karlqvist, 1987). In Southern Sweden, the mean annual evaporation from an open water surface is $450 \mathrm{~mm}$ (Bengtsson et al., 1994).

Normally, constructed wetlands are located outside the landfill and are subject to national regulations (Robinson, 1992). Therefore it may be, advantageous to locate the wetland on top of the landfill. Besides the treatment effects, it may also decrease the leachate discharges from the landfill as the annual evapotranspiration is supposed to exceed the annual precipitation and also the risk for groundwater contamination. 


\section{DESCRIPTION OF THE CONSTRUCTED WETLAND AT HEDESKOGA LANDFILL}

The Hedeskoga landfill has a total area of about 14 hectares. The operation of the landfill, designed to receive domestic and industrial waste, started in 1973. Today, it receives waste from three districts serving a total of 70, 000 inhabitants. The landfill generates about 50, 000 cubic metres of leachate per year, most of it in early spring and late autumn (Figure 2) (Thörneby, 1996; Hogland et al.,1996).

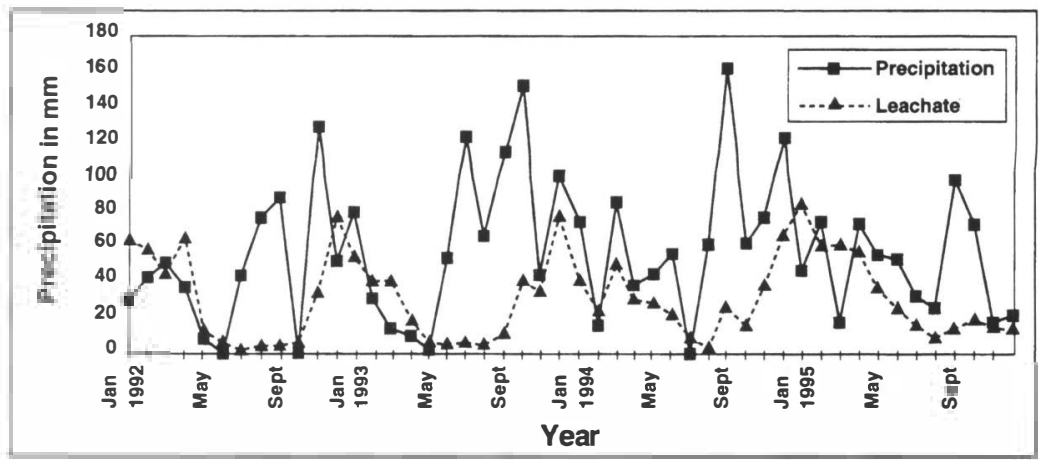

Fig. 2: Precipitation and leachate production at Hedeskoga landfill site 19921995.

The ratio of BOD to COD is about 0.1 , which indicates that Hedeskoga landfill is mainly in methanogenic phase. This, together with low levels of biodegradable and chemically degradable organics, and a low ratio of sulphate to chloride, indicates that the majority of the leachate emanates from older waste. Most of the nitrogen is, as expected, in the form of ammonia.

During 1996, test runs with a reverse osmosis pilot plant without any leachate pre-treatment, were performed. The results show an initially high flux, but the flux decreases very rapidly (Figure 3), indicating problems with fouling substances, that is, mainly iron but some organics were also present. 


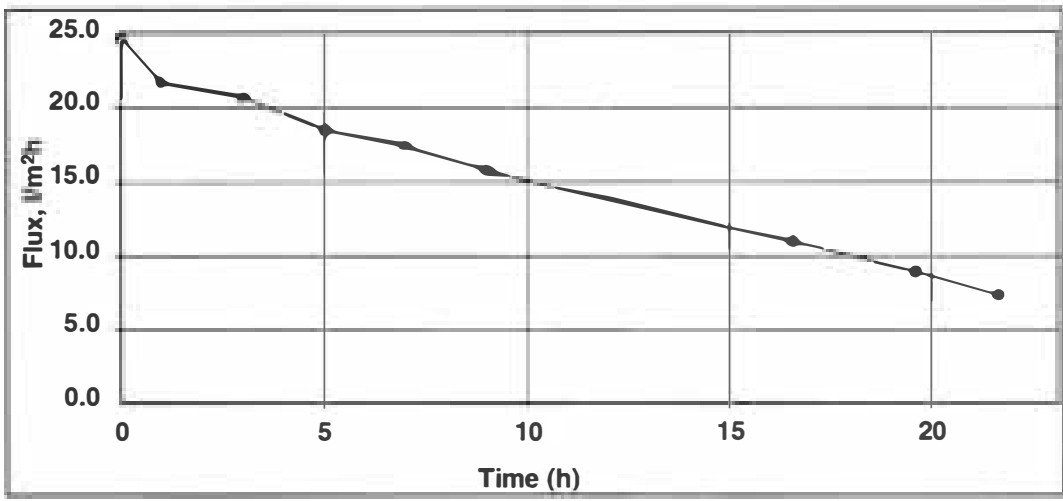

Fig. 3: Reduction in flux without pre-treatment of leachate.

The steep slope of the line is due mostly to the high iron concentration in the leachate at Hedeskoga.

It was necessary to clean the membrane daily with an acid to remove inorganics followed by an alkali detergent to remove organics. There were also problems in reaching the national requirements of nitrogen content of the effluent. On the basis of these results a wetland system, is installed as a pre-treatment system. The wetland will be run at a high hydraulic load and the effluent will be polished by the reverse osmosis plant (Figure 4). The reverse osmosis plant will be equipped with spiral wound membranes, which, together with an expected reduction in leachate volume due to increased evapotranspiration, will decrease the treatment costs.

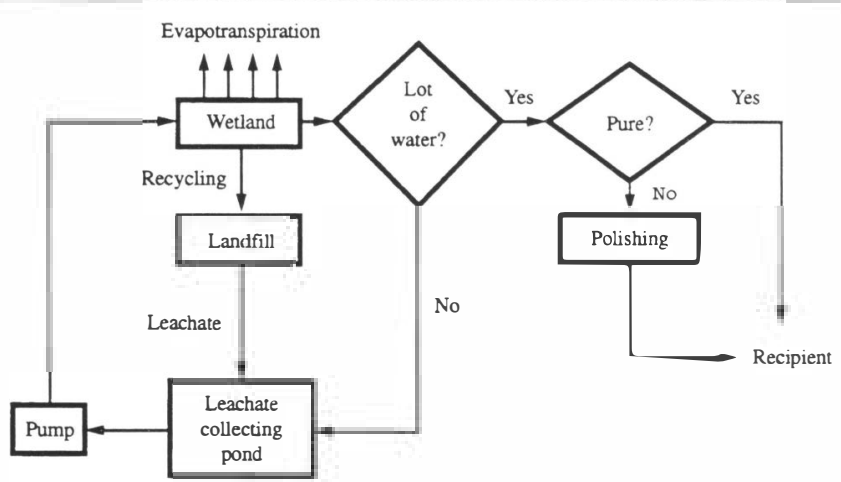

Fig. 4: Flowchart of the leachate treatment system, with wetland, recycling and polishing. 
The constructed wetland at Hedeskoga Landfill is equipped with impermeable bottom liner beneath the clay liner and a drainage layer between them, making it possible to measure the amount infiltrated water (Figure 5). This will improve the understanding of wetland water balances, treatment efficiency - both in the bed and in the bottom liner - and short and long term infiltration rates.

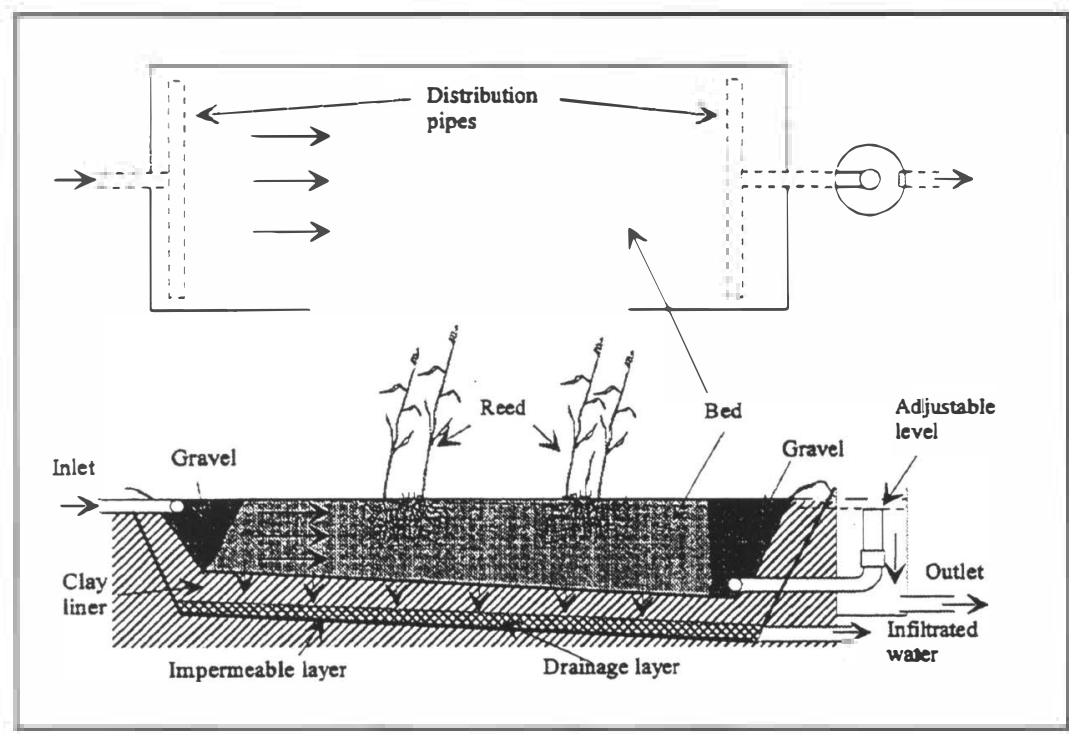

Fig. 5: Constructed wetland design

\section{SYSTEM AND EXPECTED PERFORMANCE}

The construction of wetlands on top of landfills combines several treatment methods such as biodegradation, adsorption, precipitation, volume reduction and recirculation of leachate. As no special liner is necessary to protect ground water, it also allows the optimisation of biogas production and increases the stabilisation rate of the organic waste. Figure 6 shows a summary of physical, chemical and biochemical treatment effects which take place in the constructed wetland, the liner and the landfill body. 


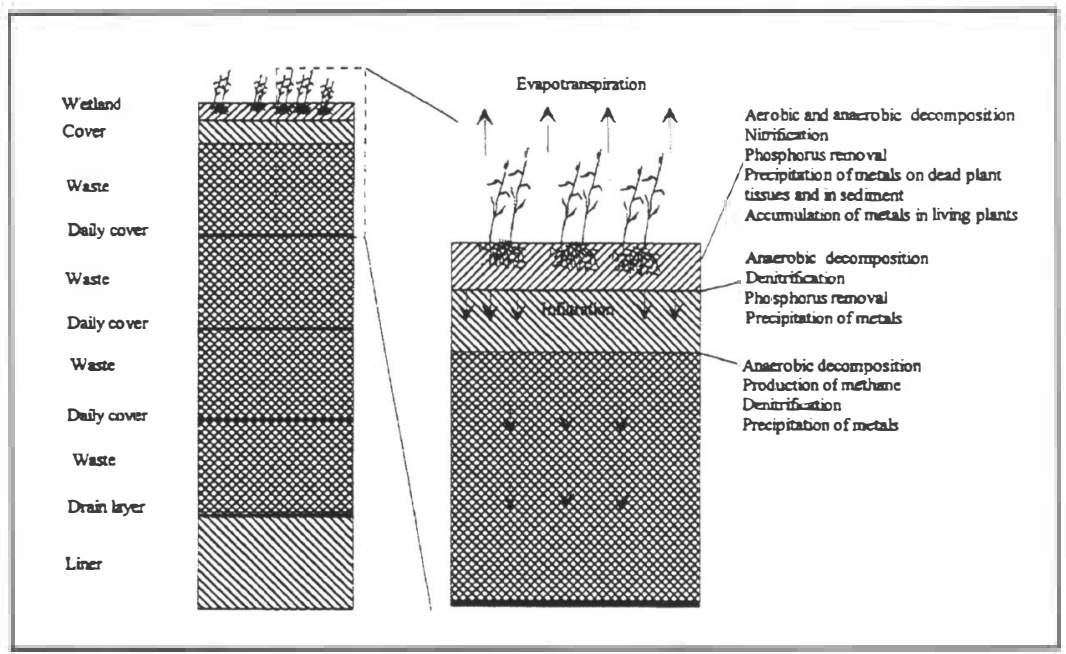

Fig. 6: Cross section of a landfill with on top wetland and also expected physical, chemical and biochemical effects.

Wetland systems, which only cover a part of the total landfill area, might require a non-biological polishing step such as reverse osmosis during periods with high hydraulic loads and low microbiological activity. Also when the recipient is sensitive to contaminants such a treatment system will be cost effective due to the pure effluent from the constructed wetland.

Contrary to off-site wetland systems, on-site systems make it possible to decrease the amount of leachate produced at the landfill (Figure 7).

The annual outflow of leachate $Q_{\text {eff }}$ from the landfill may be calculated by the equation

$$
Q_{E F F}=\left(P-E T_{L}\right) e^{*}(1-b)+\left(P-E T_{C W}\right) * b
$$

where; $P$ is actual annual precipitation; $E T_{C W}$ is the annual evapotranspiration from the wetland area; $E T_{L}$ is the evapotranspiration from landfill area not covered by wetland and; $b$ is the part of the whole landfill area covered by wetland. 


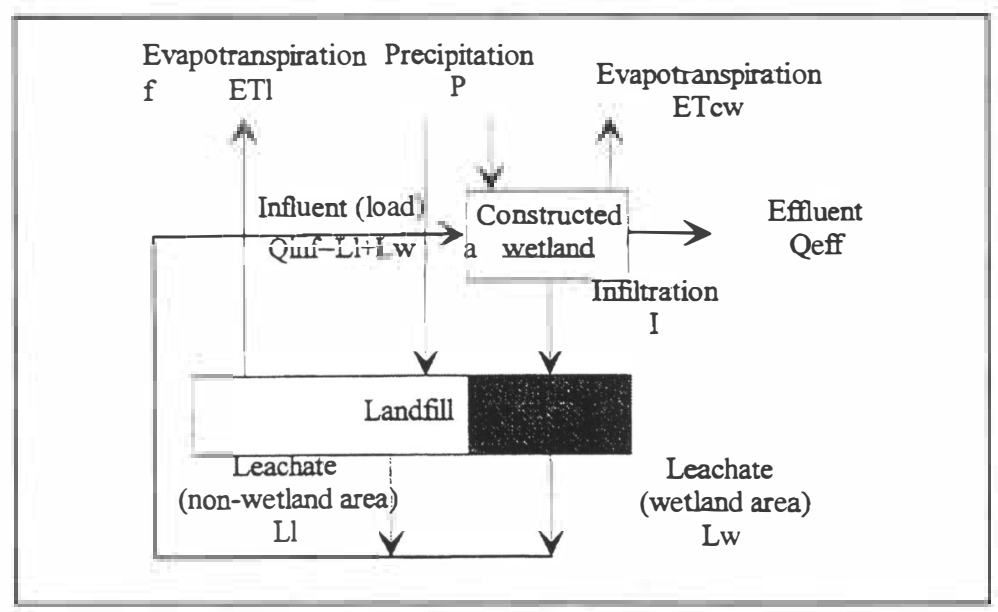

Fig. 7: Water balance of on-site constructed wetland

Using precipitation values from Southern Sweden $(P=700 \mathrm{~mm})$ and estimated values for evapotranspiration $\left(E T_{L}=300 \mathrm{~mm}, E T_{C W}=800 \mathrm{~mm}\right)$ and a wetland area of $25 \%$ of total landfill area, the mean daily effluent from the landfill will $275 \mathrm{~mm} / \mathrm{yr}$ compared to $400 \mathrm{~mm} / \mathrm{yr}$ without wetland. It is possible to achieve zero effluent from the landfill if $80 \%$ will be covered by a subsurface wetland.

The constructed wetland will be planted with common reed next spring, but the evaporation test has begin during autumn this year. Also tests of the treatment efficiency in the bed without reed and treatment efficiency in the liner will be performed at the same time in order to determine the performance during cold periods. Furthermore, research will be done on optimising nitrogen removal as soon the wetland is vegetated. Tests will also be performed with reverse osmosis on the effluents from the wetland, both with tubular and spiral wound membranes.

\section{CONCLUSION}

By appropriate design of a constructed wetland, it may be possible to reduce the total leachate flow from a landfill by $20 \%$ to $50 \%$, depending on the ratio between the wetland and the drained landfill area.

\section{ACKNOWLEDGEMENT}

The authors want to thank The Swedish Federation of Civil Engineers, The Foundation REFORSK and The Swedish Board for Industrial, Technical Development (NUTEK) and The waste management company AB ASSY for their financial support to the project. Thanks is also directed torwards Anders Linde'n at AB ASSY by his technical/practical support on site. 


\section{REFERENCES}

Bavor, H.J., Roser, D.J., Adcock, P.W., (1995). "Challenges for the development of advanced constructed wetlands technology.", Water science and technology, 32(3), 13-20.

Bengtsson, L., Bendz, D., Hogland, W., Rosquist, H., Åkesson, M., (1994). "Water balance for landfills of different age." Journal of Hydrology, 158.

Brix, H., (1987). "Treatment of wastewater in the rhizosphere of wetland plants the root zone method." Water Science and Technology, 19:107.

Davido, R. L., Conway, T. E., (1989). "Nitrification and Denitrification at the Iselin Marsh/Pond/Meadow Facility," in Constructed Wetlands for Wastewater Treatment: Municipal, Industrial and Agricultural, "Proceedings from the First Intermational Conference on the Constructed Wetlands for Wastewater Treatment held in Chattanooga, Tn. on June 13-17 1988", Hammer Donald A., ed., Lewis Publishers, Chelsea, Michigan.

Gersberg, R.M., Elkins, B.V., Goldman, C.R., (1983). "Nitrogen Removal in Artificial Wetlands.” Water Research., 17(9), 1009-1014.

Gersberg, R. M., Elkins, B. V., Goldman, C.aR., (1984). "Nitrogen removal in artificial wetlands." Water Research, 17.

Henigin, P. L. A., (1995). "Recirculation of Leachate Concentrate from Reverse Osmosis Treatment.", Sardinia 95 Fifth Int. Landfill Symposium.

Hogland, W., Persson, K., \& Thörneby, L. (1996) "Treatment of Landfill Leachate with Reverse Osmosis in Southern Sweden". Waste Management - In Crisis, Wastecon'96, 17-20 September, Durban, South Africa.

Jaeffer, A E., (1994). "The application of a novel chemical treatment program to mitigate scaling and fouling in reverse osmosis units.", Desalination, 96(1-3), $71-79$.

Karlqvist, L., (1987). "Hydrogeological aspects of leachate production at disposal sites." Licentiate Dissertation, Rep. 125, Quaternary Geology, Uppsala University

Kickuth, R., (1977). "Degradation and incorporation of nutrient from rural wastewaters by plant rhizosphere under limnic conditions, Utilisation of Manure by Land Spreading", Comm. of the Europ. Communities, EUR 5672e, London, pp 335.

Lind, A., (1996). "Rotzonsanläggning inte allena saliggörande." VAV-nytt, 96(1). 
Marinas, B.J., (1991). "Reverse osmosis technology for waste water reuse." Water science and technology, 24(9), p 215-227

MacIntyre, B. D., Riha, S. J., (1991). "Hydraulic conductivity and nitrogen removal in an artificial wetland system." J. of Environmental Quality 20(Jan.Mar).

Rautenbach, R., Albrecht, R., (1989). "Membrane Processes." Wiley, 459p.

Rautenbach, R., Linn, T., (1996). "High-pressure reverse osmosis and nanofiltration, a "zero discharge" process combination for the treatment of wastewater with sever fouling/scaling potential." Desalination, 105(1-2), 63-70.

Reed, S. C., Middlebrooks, E. J., Crites, R. W., (1987). "Natural systems for waste management and treatment." McGraw-Hill Book Co. New York.

Reddy, K.R., D'Angelo, E.M. DeBusk, T.A., (1989). "Oxygen Transport through Aquatic Macrophytes: Their Role in Wastewater Treatment." Journal of Environmental Quality, 19, 261-267.

Robinsson, H. D., Barr, M.J., Last, S. D., (1992). "Leachate collection, treatment and disposal." Journal of the institution of water and environmental management, 6(3), 321-332.

Robinsson, H. D., (1993). "The treatment of landfill leachates using reed bed systems." Sardinia 93 Fourth International Landfill Symposium.

Rome, L., Gronow, L., (1995). "Leachate recirculation in the UK: an overwiew of research projects." Sardinia 95 Fifth International Landfill Symposium.

Sand-Jenssen, K., Prahl, C., Stokholm, H., (1982).”Oxygen Release from Roots of Submerged Aquatic Macrophytes." Oikos, 38, 349-354.

Steiner, G. R., Freeman, R. J. Jr., (1989) "Configuration and substrate design considerations for constructed wetlands wastewater treatment." in Constructed Wetlands for Wastewater Treatment: Municipal, Industrial and Agricultural, "Proceedings from the First International Conference on the Constructed Wetlands for Wastewater Treatment held in Chattanooga, Tn. on June 13-17 1988", Hammer Donald A., ed., Lewis Publishers, Chelsea, Michigan.

Thörneby, L., Hogland, W., Persson, K., (1996). "Uppförande av omvänd osmosanläggning för behandling av lakvatten från deponi - Etapp 2." REFORSK, 131, Sweden.

Wetsel, P. R., (1984) "The use of wetlands for wastewater treatment: An introduction." National Wetlands Newsletter, v.6 September/October, 1984. 
Wetsel, P. R., (1984) "The use of wetlands for wastewater treatment: An introduction." National Wetlands Newsletter, v.6 September/October, 1984. 